\title{
Deprivation or Discrimination? \\ Comparing Theories of the Reverse Income-Obesity Gradient in the U.S. and South Korea
}

\author{
SeungYong Han $^{1}$ and Daniel J. Hruschka ${ }^{2}$
}

Total Word Count (excluding abstract, references and tables): 5,955

Number of Tables: 4 main and 7 appendix tables

Number of Figures: 2

Running Head: Comparing Two Theories of the Reverse Income-Obesity Gradient

\footnotetext{
${ }^{1}$ Mayo Clinic/Arizona State University Obesity Solutions Initiative

${ }^{2}$ School of Human Evolution and Social Change, Arizona State University

Corresponding Author: Seung-Yong Han, Obesity Solutions, Arizona State University, 1000 Cady Mall Suite 164, Tempe, AZ 85287, USA.

Email:shan32@asu.edu
} 


\begin{abstract}
In high-income countries, poverty is often associated with higher average body mass index (BMI). To account for this reverse gradient, deprivation theories posit that declining economic resources make it more difficult to maintain a healthy weight. By contrast, discrimination theories argue that anti-fat discrimination in hiring and marriage sorts heavier individuals into lower-income households. We assess competing predictions of these theories by examining how household income in representative samples from South Korea $(2007-2014, \mathrm{~N}=20,823)$ and the U.S. (1999-2014, N=6,395) is related to BMI in two key contrasting groups: (1) currently married and (2) never married individuals. Naïve analyses that aggregate these two groups reveal the well-established reverse gradient. Stratified analyses, on the other hand, reveal that the gradient only appears among currently married women, but not never-married women or men. Further analyses indicated that these differences in the gradient by marital status cannot be accounted for a number of alternative hypothesis based on differential employment or motivation to lose weight. Though consistent with predictions of anti-fat discrimination in marriage, these findings raise important challenges to deprivation theories of the reverse gradient.
\end{abstract}

Keywords: reverse gradient, income, body mass index, NHANES, KNHANES 


\section{Deprivation or Discrimination? Comparing Two Theories of the Reverse Income-Obesity Gradient in the U.S. and South Korea}

\section{BACKGROUND}

An increasingly well-established finding in the social sciences and population health is an inverse relationship between body mass index (BMI) and income in high-income countries. Specifically, heavier individuals on average live in lower-income households, a phenomenon often referred to as the reverse gradient in obesity (Dinsa et al. 2012; Hruschka 2012; Monteiro et al. 2004; Sobal and Stunkard 1989; Subramanian et al. 2011). This is a reversal of the trend observed among the poorest 80 percent of contemporary humanity, where increasing income on average leads to increasing body weight (Hruschka, Hadley, and Brewis 2014). The simultaneous increase in economic resources and body size experienced by most contemporary humans fits a simple model: more economic resources permit individuals to consume calories and to become fatter (Brown and Konner 1987; Eaton, Konner, and Shostak 1988; Hruschka 2012).

The reversal of the relationship between income and BMI in high-income countries poses more puzzles and has inspired a number of theoretical explanations. The origins of the reverse gradient are highly relevant to theories of how social stratification and human biology interact to create observed disparities in health and achievement (House 2002; Olafsdottir 2007; Phelan, Link, and Tehranifar 2010; Sobal and Stunkard 1989). They are also of particular interest to policymakers and public health practitioners aiming to reduce health disparities and to alleviate the disease burden of obesity (Drewnowski 2009). 
Since Sobal and Stunkard (1989) first described the reverse gradient more than 25 years ago, researchers have proposed a number of explanations for it. Most current theories posit that greater income gives people the ability to achieve society's ideals for body size and shape, while individuals living in lower-income households do not have the economic capacity to do so. For example, Sobal and Stunkard $(1989,266)$ suggested a large body might be a "sign of health and wealth" in poorer countries, but in wealthier settings, this can shift from an ideal to a stigmatized condition. As these ideals shift, wealthier individuals also use their economic capacity to attain the new thin ideal. Sobal and Stunkard did not commit to the specific mechanisms by which people with higher incomes were better able to approximate body size ideals. Recently, however, scholars have provided a number of more fully elaborated accounts based variously on food choice constraints, leisure exercise opportunities, and time pressures on food preparation (Hruschka 2012). Two recurring assumptions of these deprivation theories are that (1) people actively work to change their bodies to fit current ideals, and (2) people with greater income can change their body size by consuming the costly foods and engaging in the physical activity necessary to achieve those ideals.

Although deprivation theories have been the favored source of explanations for the reverse gradient in obesity, a second class of theories based on anti-fat discrimination are also potentially relevant. Such theories reverse the direction of causation and posit that anti-fat discrimination in hiring and marriage can lead individuals with higher BMI to be selected into lower-paying jobs and lower-income households (Cawley 2004; Conley and Glauber 2007; Glass, Hass, and Reither 2010; Mason 2012; Malcolm and Kaya 2016; Oreffice and Quintana-Domeque 2016). Such discrimination can happen for a range of reasons, including preferences for attractive partners and employees and weight-based judgments of competence and motivation that can 
affect both educational opportunities and hiring (Crandall and Schiffhauer 1998; Greenberg et al. 2003; Puhl and Brownell 2003; Crosnoe \& Muller 2004; Puhl, Andreyeva, and Brownell 2008; Puhl and Heuer 2009; Glass, Hass \& Reither 2010; Flint and Snook 2014). Notably, explanations based on anti-fat discrimination do not require that individuals have any capacity to manipulate their own weight. Rather, discrimination theories simply assume that there is some pre-existing variation in the population and that anti-fat discrimination acting on this variation leads to a negative correlation between BMI and household economic resources.

Despite their potential relevance, such anti-fat discrimination theories have rarely been proposed as explanations in the hundreds of papers currently published on the reverse gradient in obesity. And although a number of studies demonstrate such anti-fat discrimination in both marriage and labor markets, it is not clear whether such discrimination could create reverse gradients of the magnitude observed in high-income countries (Baum and Ford 2004; Cawley 2004; Judge and Cable 2011; Oreffice and Quintana-Domeque 2010; Ponzo and Scoppa 2015). One key challenge in comparing the explanations from deprivation and discrimination theories is that they often make identical empirical predictions, and isolated tests of these predictions against simple null hypotheses cannot differentiate between these explanations. This paper seeks to unite these two theoretical literatures to identify one set of contrasting predictions related to the reverse gradient in obesity and to assess the relative agreement of these contrasting predictions with data from representative samples of men and women in two high-income countries - the United States and South Korea. We analyze data from these two countries to assess the consistency of results across two culturally distinct countries where a reverse gradient has been observed.

\section{Deprivation and Obesity}


Current explanations for the reverse gradient in obesity nearly exclusively derive from some version of a deprivation-based theory (Parsons et al., 1999; Giskes et al., 2008; Drewnowski 2009). These represent a broader class of theories for health disparities which posit that increasing resources should give individuals more opportunities to achieve healthier outcomes (Adler and Newman 2002; Pampel, Krueger, and Denney 2010). Researchers have proposed a number of mechanisms that could increase the risk of obesity among poorer individuals. For example, the energy density hypothesis is built on the observation that foods lower in energy density (such as vegetables) can protect against obesity but also cost more per calorie. Consequently, wealthy individuals are best able to consume the costly diets necessary to fit an ideal of thinness (Drewnowski and Specter 2004; Drewnowski and Darmon 2005; Drewnowski 2009). A related theory, the protein leverage hypothesis, is built on the observation that protein costs 20 to 50 times more per calorie than other macronutrients, such as fat and carbohydrates. Evidence also suggests that protein is more satiating than other macronutrients and humans will continue to consume food until they have reached a certain amount of protein. Accordingly, in low-income situations, individuals will purchase cheaper low-protein alternatives that do not satiate and thus encourage consumption of excess calories (Brooke, Simpson, and Raubenheimer 2010; Simpson and Raubenheimer 2005). A third argument focuses on economic constraints on physical activity by proposing that wealthier individuals have more of the kinds of opportunities for physical activity —including leisure time as well as safe public and private spaces for exercise —needed to shape their bodies to fit society's ideals (Gordon-Larsen et al. 2006). A unifying assumption of all of these theories is that people can effectively deploy additional economic resources to lose weight or maintain a lower weight, and that people who do not have these resources are constrained in their ability to do so. 
These different deprivation hypotheses have empirical support in a large and growing number of cross-sectional studies (Drewnowski 2009). However, finer-grained tests of these theories examining historical trends or using mediation analyses have shown mixed results. For example, one analysis of BMI trends over three decades in the U.S. suggests that increased portion size and more frequent eating were more important factors than the energy density of food in increasing BMI in the U.S (Duffey and Popkin 2011). Moreover, the energy density of foods does not appear to account for a very large proportion of the effect of social class on obesity (Aggarwal et al. 2011). When focusing on protein, instead, experimental and population-based studies have shown either (1) no effect of protein on energy intake and obesity, or that (2) these effects depend on specific kinds of protein (Blatt, Roe, and Rolls 2011; Bujnowski et al. 2011; Lin et al. 2011; Vinknes et al. 2011). In historical perspective, very few cases of longitudinal increases in economic resources are associated with longitudinal declines in BMI over the same period of time (Hruschka 2012). Thus, although cross-sectional associations of income with obesity are consistent with deprivation theories, finer-grained analyses based on longitudinal data and mediation analyses show inconsistent results.

\section{Anti-Fat Discrimination}

Deprivation theories have been the dominant explanation for reverse gradients in obesity. However, a second class of theories based on anti-fat discrimination might also account for the observed negative associations between BMI and income (Averett and Korenman 1993; Averett, Sikora, and Argys 2008; Chiappori, Oreffice, and Quintana-Domeque 2012; Conley and Glauber 2007; Morris 2007; Mukhopadhyay 2008; Oreffice and Quintana-Domeque 2010; Glass, Hass, \& Reither 2010). In the last three decades, social scientists and public health researchers have consistently documented anti-fat discrimination in the U.S. and European countries (Chen and 
Brown 2005; Crandall and Schiffhauer 1998; Flint and Snook 2014; Greenberg et al. 2003; Puhl, Andreyeva, and Brownell 2008; Puhl and Heuer 2009). Not thoroughly studied quantitatively yet, South Korea also serves as a useful case study of weight discrimination with its extremely high level of weight stigma against big body sizes (Jung and Lee 2006; Marini et al. 2013; Schwekendiek, Minhee, and Ulijaszek 2013).

Two possible pathways could explain how anti-fat discrimination could give rise to the observed reverse gradient in obesity. Labor market discrimination in the processes of hiring, promotion, and retention is one potential pathway leading individuals with higher BMIs to have lower personal incomes. Body mass index is a specific example of a wider range of individual physical characteristics, including height and facial attractiveness, that appear to garner premiums or incur penalties in labor markets (Averett and Korenman 1996; Glass, Hass, \& Reither 2010). Numerous studies in the U.S. and Europe have demonstrated how BMI can influence salaries, especially among women (Baum and Ford 2004; Cawley 2004; Judge and Cable 2011). However, it is not clear whether such discrimination can generate gradients of the magnitude observed in the U.S. and other countries (Hruschka 2017).

Anti-fat discrimination in the marriage market is another pathway that can generate negative correlations between BMI and household income. As opposed to labor market discrimination, marital discrimination should theoretically lead to negative correlations between BMI and a spouse's income (or overall household income), but not necessarily personal income. This has been shown empirically in a number of studies (Burdett and Coles 2001; Carmalt et al. 2008; McClintock 2014; Sassler and Joyner 2011; Stevens, Owens, and Schaefer 1990; Taylor and Glenn 1976; Udry 1977). The effects of both marital and labor market discrimination should be particularly pronounced in the highest income segments of contemporary humanity - those living 
in high-income countries, and high-wealth populations in middle- and even low-income countries - where increasing resources no longer bring appreciable increases in caloric consumption or related gains to body weight (Hruschka 2012; Hruschka, Hadley, and Brewis 2014).

Substantial work in sociology has examined the various ways that partners in heterosexual marriages sort by income and physical characteristics and a range of other traits (McClintock 2014; Ponzo and Scoppa 2015). The partner selection literature frequently distinguishes between matching on the same characteristics, such as partner similarity in education, income, or height, and correlations across different traits, such as individuals with higher education marrying partners with higher incomes. Although same-trait matching and cross-trait correlations are sometimes depicted as the result of mutually exclusive processes - selecting partners based on similarity versus selecting partners based on desired traits—couples very likely engage in both (McClintock 2014). In many situations, researchers have also found gender asymmetries in cross-trait matching. For example, a few recent studies have observed correlations between individual BMI and a partner's income that are stronger for women than for men in heterosexual marriages (Oreffice and Quintana-Domeque 2010). However, this particular asymmetry does not necessarily mean that women do not prefer male partners with a lower BMI or that men do not prefer female partners with a higher income. Indeed, in this case, existing analyses suggest that both genders care about their partner's BMI and salary, but to differing degrees (Oreffice and Quintana-Domeque 2010; Ponzo and Scoppa 2015). Rather, such asymmetries simply indicate that there are some quantitative rather than categorical gender differences in preferences and socially-constrained endowments and opportunities. The roots of such differences in preferences 
are of considerable interest, and there are ongoing productive debates about their social structural and biological origins (McClintock 2014).

\section{Predictions}

There are many ways that marriage, household income, and weight can come to be related to each other, and mechanisms described in both of these theories may simultaneously play roles in creating such reverse BMI gradients (Pudrovska et al., 2014). In many cases, these differing explanations for the reverse gradient — deprivation, labor market discrimination, and marital discrimination - are all consistent with coarse-grained associations between income and BMI. Thus, it can be useful to identify contrasting predictions of the different theories as a way to compare them.

Here we focus on contrasting predictions about the association of household income with BMI among never-married women. Deprivation theories propose individuals with lower household incomes will have fewer opportunities to maintain a healthy weight through diet and exercise. Importantly, current descriptions of such theories do not explicitly make differing predictions based on whether someone has never married or is currently married. In either case, household income is considered a key driver of the association. Theories based on anti-fat discrimination in labor markets also do not explicitly make differing predictions about the relationship of household income and BMI for never-married or currently-married individuals. If higher individual BMI is leading to lower personal income, then higher individual BMI should also lead to lower household income. Crucially, explanations based on anti-fat discrimination in marriage do lead to contrasting predictions for never-married and currently-married individuals. Specifically, if anti-fat discrimination in heterosexual marriage can account for observed reverse gradients, then we should observe no correlation between household income and BMI among 
individuals who have never entered into a marriage (see Figure 1). Conversely, we should see a negative correlation between household income and BMI among individuals who have entered into a marriage.

The expected direction of the association of household income and BMI under each theory is graphically summarized in $<$ Figure $1>$. Of crucial importance for this theoretical comparison is differences in the slopes relating household income and BMI, rather than simple mean differences in BMI between married and never married individuals that might be due to marriage increasing BMI or BMI shaping the probability of getting married (Umberson et al. 2009; Glass, Hass \& Reither 2010; Pudrovska et al. 2014).

To compare these two explanations for the reverse gradient in obesity, we assess their contrasting predictions in nationally representative samples from two high-income countries with very different cultural backgrounds - South Korea (2007-2014) and the U.S. (1999-2006) - to see if the results generalize across diverse cultural contexts. We focus our comparison on currently married and never married individuals, because the discriminating predictions of the two theories are most clearly different for these two groups (see below). To replicate past analyzes, we first conduct a naïve analysis without stratifying on marital status. We then examine the interaction between marital status and household income to see if the reverse gradient is observed among both currently and never married individuals (consistent with deprivation theories) or is observed only among currently married individuals (consistent with discrimination theories). We also conduct a number of additional sensitivity analyses that assess alternative hypotheses based on differences between currently and never married individuals in age, employment and motivation to manage their weight. 


\section{DATA AND METHOD}

Two datasets were used for the analysis: the National Health and Nutrition Examination Survey (NHANES 1999-2014) and the Korean version of NHANES (KNHANES 2007-2014). Both NHANES and KNHANES were designed to examine the health and nutritional status of children, adolescents, and adults living in the United States and South Korea, respectively (CDC 2014; KCDC 2014). To analyze patterns in Korea, we used KNHANES IV (2007-2009, KCDC 2007), V (2010-2012, KCDC 2010), and VI (2013-2015, KCDC 2013). The 2015 data has not yet been released at the time of analysis, so the datasets between 2007 and 2014 were merged for the analysis. To analyze patterns in the United States, we used the continuous NHANES data collected between 1999 and 2014.

The final sample includes those Korean and American non-pregnant respondents in KNHANES and NHANES with ages between 20 and 49 years old. Further, only Non-Hispanic White participants were considered in NHANES as they have consistently shown a reverse gradient in obesity, and they comprised a large enough sample size for comparison with KNHANES (Hruschka 2017). Because South Korea is racially and ethnically homogenous with relatively few immigrants, ethnicity was not restricted for the analysis of KNHANES.

Limiting the samples to currently married and never married individuals provides the cleanest comparison of the predictions. Specifically, those who are never married have not had the opportunity to gain income through marriage whereas those who are currently married have a household income that most directly reflects income gains through marriage (as well as their own income). By contrast, individuals who are widowed or divorced may have household income that reflects gains from past marriages to an unknown degree (e.g. alimony or dividends from a spouse's savings or pension). For this reason, those respondents who were divorced, widowed, or 
separated at the time of the survey were excluded from the sample (4\% of KNHANES and $12 \%$ of NHANES samples). Cohabitation was recorded in the NHANES, but not KNHANES, datasets, so we focus analyses on formally married versus never married individuals (Cohabiting individuals were $10 \%$ of U.S. sample). As a result, the non-weighted final sample sizes are 20,823 (female $=11,835$ and male $=8,988$ ) for KNHANES and 6,395 (female $=3,089$ and male $=3,306$ ) for NHANES. We also conduct sensitivity analyses in supplementary materials that included cohabiting with currently married individuals in the U.S. sample.

\section{Measures}

Assessing BMI \& obesity: BMI was used as an outcome variable in the analysis. Scholars generally describe the reverse gradient using BMI, assuming that BMI is a good proxy for body fat (Dinsa et al. 2012; Hruschka and Brewis 2013; Hruschka 2012; Monteiro et al. 2004; Sobal and Stunkard 1989; Subramanian et al. 2011). However, body mass confounds fat mass with the rest of the body's tissue, including bone, muscle, and water. Thus, some caveats apply when interpreting BMI as a measure of fat. First, sex differences in body composition mean that women generally have larger quantities of (and variability in) body fat than men do. Conversely, men have larger quantities of and variability in lean mass. These differences in body composition mean that body mass is a closer proxy of body fat in women than in men (male $\mathrm{R}^{2}=0.78$ to 0.85 , female $\mathrm{R}^{2}=0.83$ to 0.91 ) and that body mass in men more deeply confounds fat mass and fat-

free mass (Hruschka, Rush, and Brewis 2013). These sex differences are quite remarkable and have led to ample critiques of BMI as a proxy for body fat. However, once we adjust BMI for these sex and population differences, it is a relatively good proxy for total body fat, especially for women $\left(\mathrm{R}^{2}=0.83-0.91\right)$ (Hruschka, Rush, and Brewis 2013). 
Income: In KNHANES, income level was measured by a total monthly average household income (unit=10,000 won). In NHANES, income level was measured by a poverty income ratio (PIR) defined by the U.S. Census Bureau. This income index measures the ratio of a household's income to a set income threshold. For example, if a given family has a higher-than-average income, PIR will be greater than 1 . If the family has a lower-than-average income, PIR will be less than 1. To interpret income effects as the increase in BMI per percent increase in income, we analyze log income.

Covariates: Given that education can have effects on BMI independent of income, we include education as a covariate in analyses (Monteiro et al., 2001). In both NHANES and KNHANES, education level is grouped into three categories for a direct comparison across the two countries: less than high school education, high school graduate, and college graduate or above. This grouping accounts for differences in the education system through high school between Korea and the U.S. (6-3-3 system in Korea and 5-3-4 system in the U.S.).

We also include a number of covariates aimed at ruling out alternative hypotheses for observed patterns. First, if we observe an effect of income on BMI among currently-married individuals, but not never-married individuals, this could be due to greater motivation to lose weight among currently-married individuals. To assess the potential confounding role of motivation to lose weight, we control for reported efforts to lose weight. Second, an alternative account for this pattern is due differences in employment status that can influence available time for weight maintenance. For example, if never married individuals are more likely to have a job than currently married individuals, they may be less likely to have the time necessary to translate higher income into better weight maintenance. To assess this possibility, we include current employment as well as an interaction of current employment with household income in the 
models. Third, married households in general will on average have higher incomes than nonmarried households due to the potential to have dual earners, so we control for household size as well. Fourth, pregnancy and childbirth can have long-term effects on BMI, and so we included available variables on parity (NHANES) and gravity (KNHANES) as a covariates for analyses of the women's samples. Finally, as outlined in sample section, the analyses control for race and ethnicity through sample selection.

\section{Analysis methods}

Ordinary least square (OLS) regression model was used for the analysis. Because multiple years were merged for both NHANES and KNHANES, an appropriate sampling weight provided by $\mathrm{CDC}$ and $\mathrm{KCDC}$, respectively, was used to adjust each dataset for a different level of contribution from each year. For analysis, in SAS 9.4, PROC SURVEYMEANS and PROC SURVEYREG procedures with relevant options were used to consider a stratified multistage probability sampling design. In each procedure, Not Missing Completely at Random (NOMCAR) option was used to include cases with missing values in analysis variables for variance estimation as recommend by both $\mathrm{CDC}$ and $\mathrm{KCDC}$. In addition, domain option was used in all procedures, instead of listwise deletion, to calculate correct standard errors of estimates from the whole sample, not from subsamples (UCLA, 2016). The results from sensitivity analysis with and without a sampling weight and the options in SAS procedures show substantially identical results (see the online appendix, Tables $2 a$ and $2 b$, for further details).

We conducted analyses on each of 4 samples stratified by gender and by NHANES sample (2007-2014 KNHANES and 1999-2014 NHANES). We first fit a naïve regression predicting BMI from household income and the covariates, such as marital status, age, education, recent attempts to lose weight, and year of survey. The naïve regression does not permit an interaction 
between marital status and household income. Then we fit a regression model including an interaction between marital status and household income. Further regression analysis is conducted to assess whether any lack of a reverse gradient among never-married women can be accounted for by the preponderance of never-married women who were between 20-29 years old.

\section{FINDINGS}

\section{Descriptive results}

The descriptive statistics of the variables used for the analysis are summarized in $<$ Table $1>$. On average, women had lower BMI than men in both countries, but the difference was larger in Korea $(1.74, p<0.001)$ than in the U.S. $(0.66, p<0.001)$. Further, BMIs in the NHANES samples were higher than those in the KNHANES samples regardless of gender. More women than men were married in all samples. Both women and men lived in households with similar income levels. Direct comparison between Korea and the U.S. is difficult due to different measures of income level. Compared to Koreans, fewer Americans were educated at the college level or above, with a larger gap for males. The gap in education level between male and female respondents in each country is not significant.

\section{Model 1. Is there a reverse gradient in unstratified analyses? Nä̈ve regression model with no interaction}

The results for all two samples are summarized in $<$ Table $2 \mathrm{a}>$ for women and $<$ Table $2 \mathrm{~b}>$ for men. In both countries, household income had a significant and negative association with BMI for women. Specifically, women living in a household with higher incomes tended to have lower BMI in both countries. Consistent with prior studies, there was no significant relationship between household income and BMI among men. 
Covariates also showed significant, though not always consistent, relationships with BMI.

Currently-married women had significantly higher BMI than never-married women in Korea but not in the U.S. (see model 1), while currently-married male respondents always had higher BMI in Korea. College graduates had significantly lower BMI than high school graduates in all samples except for Korean men, who did not have any difference in BMI by education. Finally, as expected, respondents between 30 and 49 years of age had significantly higher BMI than younger respondents (20-29 years old) with the exception of Korean men aged 40-49.

\section{Model 2. Does marital status modify the relationship between household income and BMI? Regression with interaction between marital status and household income}

The interaction results from model 2 show that the effect of income observed among women was substantially modified by marital status in both countries across all the samples between 1999 and 2014 (see model 2 in Table 2a and 2b). In each of the two samples, a strong and significant reverse gradient was observed among women in the currently married samples (also see Figure 2). By contrast, the effect of household income on BMI was small and non-significant among never-married women. As with the unstratified model, no reverse gradient was observed among men in either sample. The estimated effect of income on BMI by marital status for each gender is summarized in $<$ Table $3>$. These results are robust to the addition of a number of potential confounders (e.g. employment, motivation to lose weight), and a number of different model specifications, including removing education from the model. The effect sizes of covariates did not change dramatically with the addition of interactions, and the interaction of employment status with household income was not significant.

Model 3. Does the preponderance of 20-29 year olds among never-married women explain the lack of a reverse gradient? Regression with interaction between age and household income 
The results in the previous analysis found no detectable association between BMI and income in the never-married sample, as expected exclusively by the theory of anti-fat discrimination in marriage. However, the lack of effect among never-married women may be due to the preponderance in that group of 20-29 year olds who have not yet had sufficient exposure to deprivation or to labor market discrimination to create a reverse gradient. This concern rests on the assumption that the reverse gradient will become stronger with increasing age. To assess whether the reverse gradient becomes stronger among women with increasing age, we ran a regression including an interaction term between age groups and income for both never-married and currently-married women. Among currently-married women in both countries, there was no significant interaction between age and income, indicating that there was not an increasing association between household income and BMI with increasing age ( $p$-value $>0.10)$. Among never-married women in Korea, there was also no significant interaction between age and income ( $p$-value $>0.10)$. Among never-married women in the U.S., there was a significant interaction, with the BMI-income relationships differing between 20-29 and 40-49 year olds. However, it indicated that increasing age actually led to increasingly positive associations between BMI and household income, rather than an increasing reverse gradient (see Appendix 5). Thus, there is no evidence that the reverse gradient increases with increasing age.

\section{DISCUSSION}

In nationally representative samples from two high-income countries with very different cultural backgrounds - South Korea (2007-2014) and the U.S. (1999-2014)—we show that reverse gradients in BMI are observed among women, but not men, confirming past findings about the gender-specificity of such reverse gradients (Sobal and Stunkard 1989). Relevant to the 
explanations outlined in this article, we also show that reverse gradients observed among women occur exclusively among currently-married women, and not among never-married women. These findings are largely inconsistent with current deprivation theories that posit greater household incomes (regardless of marital status) should provide opportunities for consumption of costly, thinning foods or leisure exercise to meet thin body size ideals. They are also inconsistent with theories of anti-fat discrimination in the labor market, which would predict a negative correlation between household income and BMI regardless of marital status. On the other hand, our finding of reverse gradients exclusively among currently-married women is highly consistent with an explanation of these reverse gradients based on anti-fat discrimination in marriage, whereby women with higher BMIs are selected into lower-income households through marriage markets. These findings also point to the importance of going beyond including marital status as a simple covariate in analyses of income-obesity relationships (Pudrovska 2014), to including it as an interacting variable that can fundamentally alter the processes that lead to such gradients.

These findings are consistent with theories proposing that anti-fat discrimination in heterosexual marriage - rather than some generic effect of income on BMI or anti-fat discrimination in labor markets - is a key factor in creating the reverse gradient. It is not clear whether this sorting process occurs in low- and middle-income countries, but these findings and other evidence indicate that it does occur in high-income countries (Averett and Korenman 1996; Chiappori, Oreffice, and Quintana-Domeque 2012; Mukhopadhyay 2008; Oreffice and Quintana-Domeque 2010). Importantly, this anti-fat discrimination model does not require any individual capacity to lose weight, an assumption that is consistent with challenges most people face in controlling their body sizes (Kassirer and Angell 1998). Rather, it only requires that marriage markets sort existing variation in BMI into households according to household income. 
Importantly, our analyses also rule out a number of alternative hypotheses for the pattern. One possible alternative account for the lack of a reverse gradient among never-married women is the disproportionate age distribution of never-married individuals in both countries. For example, about $82 \%$ of the sample of never-married Korean women were between 20 and 29 years old, and $69 \%$ of the comparable U.S. samples were in the same age group. If exposure to deprivation or anti-fat discrimination in labor markets only takes full effect in the $30 \mathrm{~s}$, then it is possible that the lack of a reverse gradient is due to the preponderance of 20-29-year-old never-married women in these samples. However, we found no evidence for a consistently increasing reverse gradient by age in any of the samples.

As stated in the introduction, if the reverse gradient arises through differential selection in marriage markets, it is important to emphasize that this does not mean that women only prefer higher incomes in spouses and men only prefer thinner women in these samples. These are average results accounting for a population-level phenomenon in wealthy countries. Thus they gloss over substantial variation between individuals in their preferences and goals. Indeed, evidence from other studies of marital assortment indicates both women and men in the United States often prefer spouses with thinner bodies. Rather, the real asymmetry stems in quantitative (but not categorical) gender differences in concerns about spousal income (Averett and Korenman 1996; Chiappori, Oreffice, and Quintana-Domeque 2012; Mukhopadhyay 2008; Oreffice and Quintana-Domeque 2010). Nor do these variations necessarily reflect innate biological tendencies. Indeed, it is possible that any asymmetries in preferences emerge from an already-unequal system (McClintock 2014). For example, men on average have access to higher salaries for the same effort in both South Korea and the U.S. It would be interesting to examine how a society's gender equality in wages influences the reverse income-BMI gradient by 
changing the trade-offs in marriage markets. Specifically, if asymmetries in the labor market influence mate preferences, which in turn influence the income-BMI gradient, then we would expect countries with greater gender equality in income and in access to wage markets to have a weaker (or non-existent) reverse income-BMI gradient among women. Interestingly, across the two samples considered here, we find the opposite — a weaker gradient among South Korean married women despite a much larger pay gap (36.6\% in South Korea in compared to $17.9 \%$ in the U.S. in 2013 according to OECD 2014).

There are a number of potential limitations to these analyses. We have focused here on two forms of anti-fat discrimination — in labor markets and marriage—but other forms, such as discrimination in education, may also play a role in creating reverse BMI-income gradients (Caliendo and Lee 2013; Han, Norton, and Stearns 2009; Han, Norton, and Powell 2011; Mosca 2013; Pan, Qin, and LIU 2012). Second, we focused on BMI as a measure of obesity, as this is the standard tool used in the past to identify reverse gradients in obesity. However, it is well known that BMI confounds both fat mass and fat-free mass, so it is important to emphasize that any characterization of the reverse gradient in terms of BMI confounds both fat mass and fat-free mass (Hruschka and Hadley 2016; Hruschka, Rush, and Brewis 2013). The degree to which such reverse gradients reflect differences in fat mass versus fat-free mass also remains to be studied. For example, studies in both Germany and the United States that separate fat mass and lean mass indicate that in labor markets there is a wage penalty specifically for adiposity, whereas there is actually a slight wage premium for lean mass (e.g., more muscular individuals earn higher wages than their less muscular peers) (Bozoyan and Wolbring 2011; Wada and Tekin 2010). Finally, it is possible that there is no effect of household income on BMI among never-married women because they are less actively managing their weight than are currently-married women. 
However, this is unlikely in light of recent evidence from the NHANES study that never-married women are on average equally or more likely to be managing their weight than currently-married women, and that our own efforts to control for weight management in the current study do not alter the results (Klos and Sobal 2013).

Finally, this study examined predicted cross-sectional patterns in observational data.

Observational data, whether cross-sectional or longitudinal, is always open to inferential threats from omitted variables and alternative hypotheses. However, comparing contrasting predictions from a range of competing theories at least permits us to compare those theories and establish which ones are most consistent with existing empirical data. In this case, predictions from theories of anti-fat discrimination in marriage are most consistent with the empirical patterns. However, it is possible that there are other better explanations that have not yet been proposed. We attempted to rule out three alternative explanations for the lack of association among nevermarried women - that they are less likely engage in weight management, that they have less time to translate income into weight reduction, or that they are largely young women who have not yet been sufficiently exposed to deprivation or labor market discrimination. It is also possible that further refinements to deprivation theories can also account for the interaction with marital status. In such cases, future work that examines ever finer-grained data on the dynamics of marriage and weight changes in longitudinal data should provide new paths for comparing and testing such refinements. Despite these potential limitations, the current findings are most consistent with predictions of anti-fat discrimination in marriage. They also raise serious questions about the scope and generalizability of currently prevalent explanations for the reverse gradient based on deprivation or anti-fat discrimination in labor markets. 
$<$ Table 1 $>$ Summary Statistics of Main Variables by Gender, Korea (2007-2014) and USA $(1999-2014)$

\begin{tabular}{|c|c|c|c|c|}
\hline & \multicolumn{2}{|c|}{ Korea 2007-2014 } & \multicolumn{2}{|c|}{ USA 1999-2014 } \\
\hline & Female & Male & Female & Male \\
\hline & $\begin{array}{c}\text { Mean (S.E.) } \\
\text { or } \%\end{array}$ & $\begin{array}{c}\text { Mean (S.E.) } \\
\text { or } \%\end{array}$ & $\begin{array}{c}\text { Mean (S.E.) } \\
\text { or } \%\end{array}$ & $\begin{array}{c}\text { Mean (S.E.) } \\
\text { or } \%\end{array}$ \\
\hline Body Mass Index & $22.52(0.04)$ & $24.26(0.04)$ & $27.55(0.22)$ & $28.21(0.18)$ \\
\hline Household income $\mathrm{a}^{\mathrm{a}}$ & $441.61(9.27)$ & $424.50(10.28)$ & $3.32(0.06)$ & $3.35(0.04)$ \\
\hline Household size & $3.75(0.02)$ & $3.57(0.02)$ & $3.45(0.03)$ & $3.39(0.03)$ \\
\hline Parity & $2.05(0.02)$ & & $1.47(0.03)$ & \\
\hline Currently married & $72 \%$ & $61 \%$ & $74 \%$ & $66 \%$ \\
\hline Employed & $54 \%$ & $83 \%$ & $72 \%$ & $87 \%$ \\
\hline Weight control, less & $53 \%$ & $36 \%$ & $43 \%$ & $25 \%$ \\
\hline \multicolumn{5}{|l|}{ Education } \\
\hline Did not finish HS & $8 \%$ & $6 \%$ & $9 \%$ & $9 \%$ \\
\hline Finished HS & $47 \%$ & $47 \%$ & $56 \%$ & $59 \%$ \\
\hline College or above & $45 \%$ & $47 \%$ & $36 \%$ & $32 \%$ \\
\hline \multicolumn{5}{|l|}{ Age group } \\
\hline 20-29 years old & $30 \%$ & $31 \%$ & $30 \%$ & $32 \%$ \\
\hline 30-39 years old & $34 \%$ & $34 \%$ & $32 \%$ & $31 \%$ \\
\hline $40-49$ years old & $35 \%$ & $34 \%$ & $38 \%$ & $37 \%$ \\
\hline $\mathrm{N}^{\mathrm{c}}$ & 11,835 & 8,988 & 3,089 & 3,306 \\
\hline
\end{tabular}

Note: ${ }^{a}$ Won in Korea or poverty to income ratio (PIR) in the U.S. samples; ${ }^{b}$ gravity in Korea; ${ }^{c}$ the full number of cases (pre-weight) including those with missing values in one or more variables since PROC SURVEYMEANS statement is used with NOMCAR and DOMAIN options; adjusted for sample weight; dummy variables for survey years are omitted from table. 
$<$ Table 2a $>$ Regression Estimates of Body Mass Index (BMI) on Household Income, Marital and Employment Status, Female, Korea (2007-2014) and USA (1999-2014)

\begin{tabular}{|c|c|c|c|c|c|c|c|c|}
\hline \multirow{4}{*}{$\begin{array}{l}\ln (\mathrm{HH} \text { income }) \\
* \text { Currently married }\end{array}$} & \multicolumn{4}{|c|}{ Korea, 2007-2014 } & \multicolumn{4}{|c|}{ USA, 1999-2014 } \\
\hline & \multirow{2}{*}{\multicolumn{2}{|c|}{$\begin{array}{l}\text { Model 1 } \\
\text { B (S.E.) }\end{array}$}} & \multirow{2}{*}{\multicolumn{2}{|c|}{$\begin{array}{l}\text { Model } 2 \\
\text { B (S.E.) }\end{array}$}} & \multirow{2}{*}{\multicolumn{2}{|c|}{$\begin{array}{l}\text { Model } 1 \\
\text { B (S.E.) }\end{array}$}} & \multirow{2}{*}{\multicolumn{2}{|c|}{$\begin{array}{l}\text { Model } 2 \\
\text { B (S.E.) }\end{array}$}} \\
\hline & & & & & & & & \\
\hline & & & $\begin{array}{l}-0.30 \\
(0.11)\end{array}$ & ** & & & $\begin{array}{l}-1.97 \\
(0.40)\end{array}$ & *** \\
\hline $\begin{array}{l}\ln (\mathrm{HH} \text { income }) \\
* \text { Employed }\end{array}$ & & & $\begin{array}{l}0.07 \\
(0.10)\end{array}$ & & & & $\begin{array}{l}0.55 \\
(0.43)\end{array}$ & \\
\hline $\ln (\mathrm{HH}$ income $)$ & $\begin{array}{l}-0.37 \\
(0.06)\end{array}$ & $* * *$ & $\begin{array}{l}-0.22 \\
(0.11)\end{array}$ & & $\begin{array}{l}-0.96 \\
(0.19)\end{array}$ & $* * *$ & $\begin{array}{l}-0.20 \\
(0.39)\end{array}$ & \\
\hline Currently married & $\begin{array}{c}0.86 \\
(0.15)\end{array}$ & *** & $\begin{array}{c}2.56 \\
(0.66)\end{array}$ & $* * *$ & $\begin{array}{l}-0.14 \\
(0.47)\end{array}$ & & $\begin{array}{c}1.72 \\
(0.60)\end{array}$ & ** \\
\hline Employed & $\begin{array}{l}0.07 \\
(0.07)\end{array}$ & & $\begin{array}{l}-0.32 \\
(0.60)\end{array}$ & & $\begin{array}{c}0.47 \\
(0.29)\end{array}$ & & $\begin{array}{l}-0.03 \\
(0.47)\end{array}$ & \\
\hline Attempt to lose weight & $\begin{array}{c}2.52 \\
(0.07)\end{array}$ & $* * *$ & $\begin{array}{c}2.53 \\
(0.07)\end{array}$ & $* * *$ & $\begin{array}{c}2.87 \\
(0.29)\end{array}$ & $* * *$ & $\begin{array}{c}2.91 \\
(0.29)\end{array}$ & $* * *$ \\
\hline Household size & $\begin{array}{l}0.12 \\
(0.04)\end{array}$ & $* *$ & $\begin{array}{l}0.11 \\
(0.04)\end{array}$ & $* *$ & $\begin{array}{l}0.13 \\
(0.16)\end{array}$ & & $\begin{array}{l}0.12 \\
(0.16)\end{array}$ & \\
\hline Parity $^{\mathrm{a}}$ & $\begin{array}{c}0.07 \\
(0.03)\end{array}$ & $*$ & $\begin{array}{c}0.07 \\
(0.03)\end{array}$ & * & $\begin{array}{l}-0.22 \\
(0.17)\end{array}$ & & $\begin{array}{l}-0.26 \\
(0.18)\end{array}$ & \\
\hline \multicolumn{9}{|l|}{ Education $^{b}$} \\
\hline Less than high school & $\begin{array}{l}0.71 \\
(0.15)\end{array}$ & $* * *$ & $\begin{array}{l}0.65 \\
(0.15)\end{array}$ & $* * *$ & $\begin{array}{l}0.49 \\
(0.50)\end{array}$ & & $\begin{array}{l}0.27 \\
(0.49)\end{array}$ & \\
\hline College or above & $\begin{array}{l}-0.65 \\
(0.08)\end{array}$ & $* * *$ & $\begin{array}{l}-0.64 \\
(0.08)\end{array}$ & $* * *$ & $\begin{array}{l}-2.23 \\
(0.30)\end{array}$ & $* * *$ & $\begin{array}{l}-2.18 \\
(0.30)\end{array}$ & $* * *$ \\
\hline \multicolumn{9}{|l|}{ Age group ${ }^{c}$} \\
\hline 30-39 years old & $\begin{array}{l}0.37 \\
(0.15)\end{array}$ & * & $\begin{array}{l}0.39 \\
(0.15)\end{array}$ & ** & $\begin{array}{l}2.02 \\
(0.43)\end{array}$ & $* * *$ & $\begin{array}{l}2.09 \\
(0.43)\end{array}$ & $* * *$ \\
\hline $40-49$ years old & $\begin{array}{l}1.02 \\
(0.16)\end{array}$ & $* * *$ & $\begin{array}{l}1.06 \\
(0.16)\end{array}$ & $* * *$ & $\begin{array}{l}2.86 \\
(0.51)\end{array}$ & *** & $\begin{array}{l}3.01 \\
(0.51)\end{array}$ & $* * *$ \\
\hline Intercept & $\begin{array}{l}21.46 \\
(0.35)\end{array}$ & $* * *$ & $\begin{array}{l}20.66 \\
(0.64) \\
\end{array}$ & $* * *$ & $\begin{array}{l}25.56 \\
(0.86) \\
\end{array}$ & $* * *$ & $\begin{array}{l}24.95 \\
(0.87)\end{array}$ & *** \\
\hline $\mathrm{R}$ squared & .20 & & .20 & & .09 & & .10 & \\
\hline F statistic & 131.0 & & 119.6 & & 29.40 & & 27.68 & \\
\hline $\mathrm{N}^{d}$ & 11,83 & & 11,83 & & 3,08 & & 3,08 & \\
\hline
\end{tabular}

Note: ${ }^{*} p<.05 ;{ }^{* *} p<.01 ;{ }^{* * *} p<.001$, two tailed; adjusted for sample weight; year effects are controlled but omitted; ${ }^{\text {a }}$ gravity in Korea; Reference categories: ${ }^{b}$ high school graduate as a reference group; ${ }^{\mathrm{c}} 20-29$ years old as a reference group; ${ }^{\mathrm{d}}$ the full number of cases (pre-weight) including those with missing values in one or more variables since PROC SURVEYMEANS statement is used with NOMCAR and DOMAIN options. 
$<$ Table 2b $>$ Regression Estimates of Body Mass Index (BMI) on Household Income, Marital and Employment Status, Male, Korea (2007-2014) and USA (1999-2014)

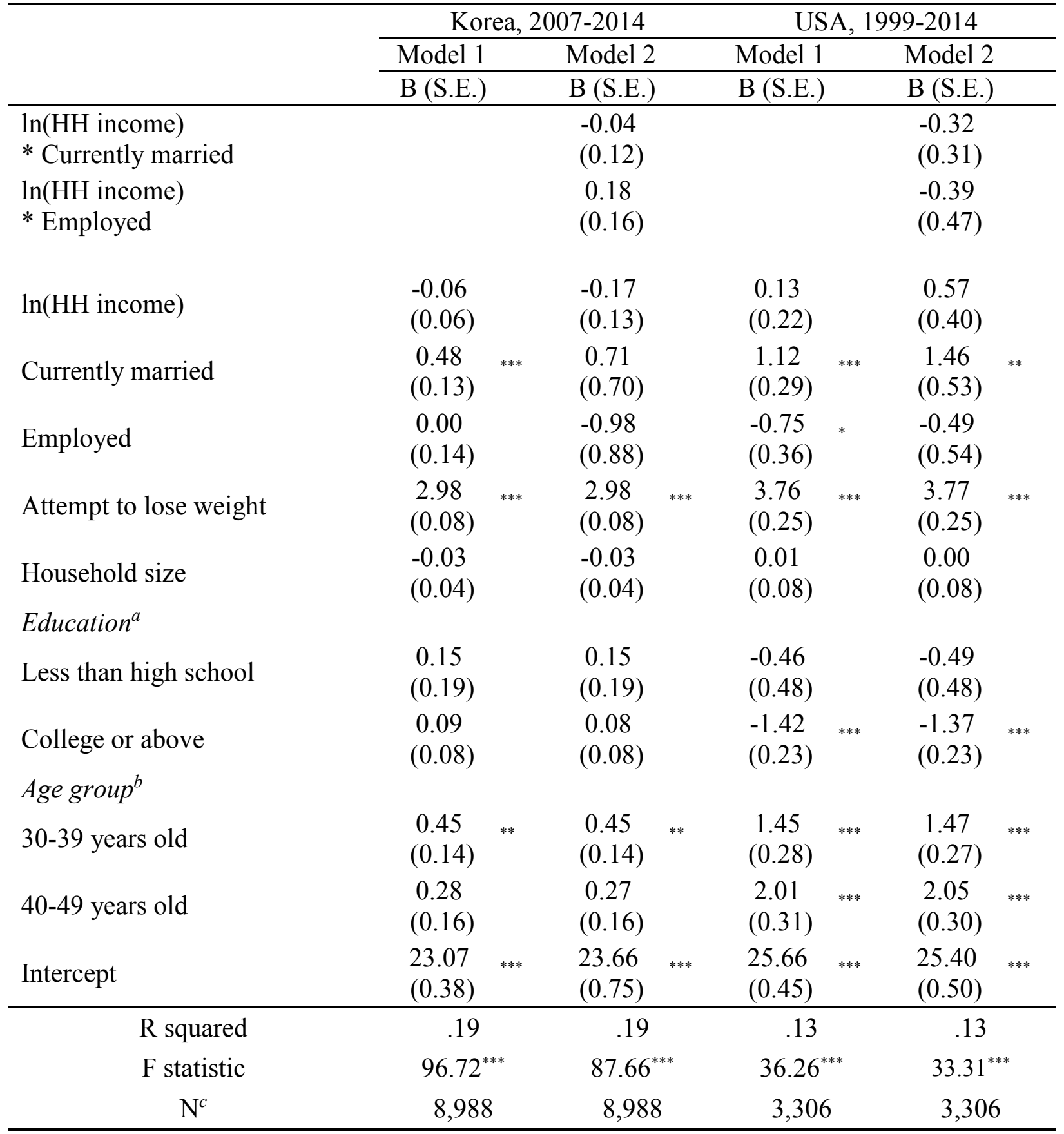

Note: ${ }^{*} p<.05 ;{ }^{* *} p<.01 ;{ }^{* * *} p<.001$, two tailed; adjusted for sample weight; year effects are controlled but omitted; Reference categories: ${ }^{a}$ high school graduate as a reference group; ${ }^{\mathrm{b}} 20-29$ years old as a reference group; ${ }^{\mathrm{c}}$ the full number of cases (pre-weight) including those with missing values in one or more variables since PROC SURVEYMEANS statement is used with NOMCAR and DOMAIN options. 
$<$ Table 3> Estimated Effects of Income on Body Mass Index by Marital Status, Korea (20072014) and USA (1999-2014)

\begin{tabular}{rcccc}
\hline & \multicolumn{2}{c}{ Female } & \multicolumn{2}{c}{ Male } \\
\cline { 2 - 5 } & $\begin{array}{c}\text { Currently } \\
\text { married }\end{array}$ & $\begin{array}{c}\text { Never } \\
\text { married }\end{array}$ & $\begin{array}{c}\text { Currently } \\
\text { married }\end{array}$ & $\begin{array}{c}\text { Never } \\
\text { married }\end{array}$ \\
\hline Korea, 2007- & -0.517 & -0.219 & -0.207 & -0.166 \\
2014 & $(-0.702 ;-0.332)$ & $(-0.472 ; 0.035)$ & $(-0.581 ; 0.166)$ & $(-0.465 ; 0.133)$ \\
USA, 1999- & -2.178 & -0.204 & 0.249 & 0.573 \\
2014 & $(-3.033 ;-1.322)$ & $(-1.097 ; 0.689)$ & $(-0.593 ; 1.091)$ & $(-0.333 ; 1.479)$ \\
\hline
\end{tabular}

Note: 95\% Bonferroni adjusted confidence interval in parentheses; adjusted for sample weight. 
$<$ Figure 1 $>$ Expected hypothetical association between income and body mass index (BMI) by deprivation and anti-fat discrimination theories

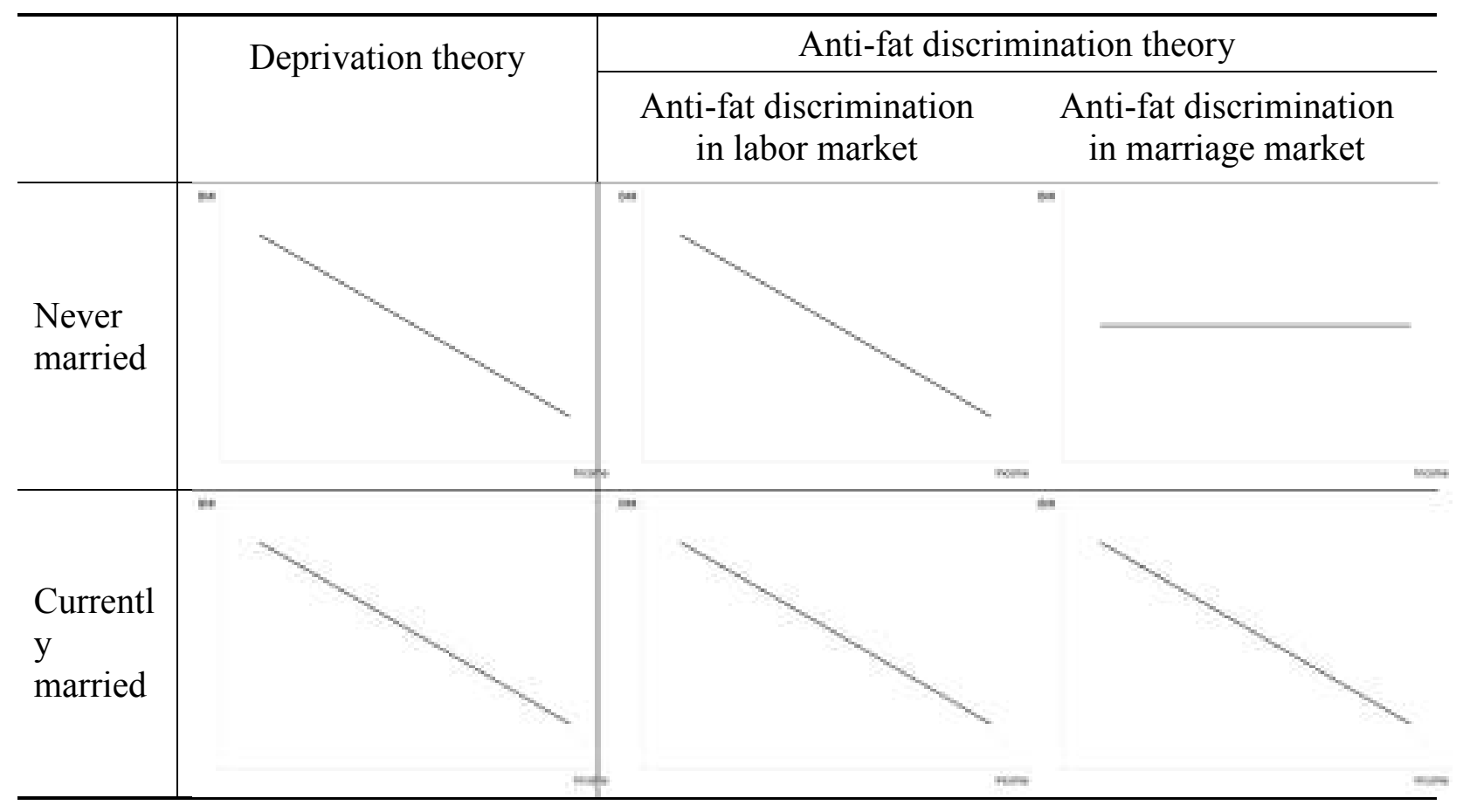


$<$ Figure 2> Estimated Effects of Income on Body Mass Index (BMI) by Marital Status, Korea (2007-2014) and USA (1999-2014)
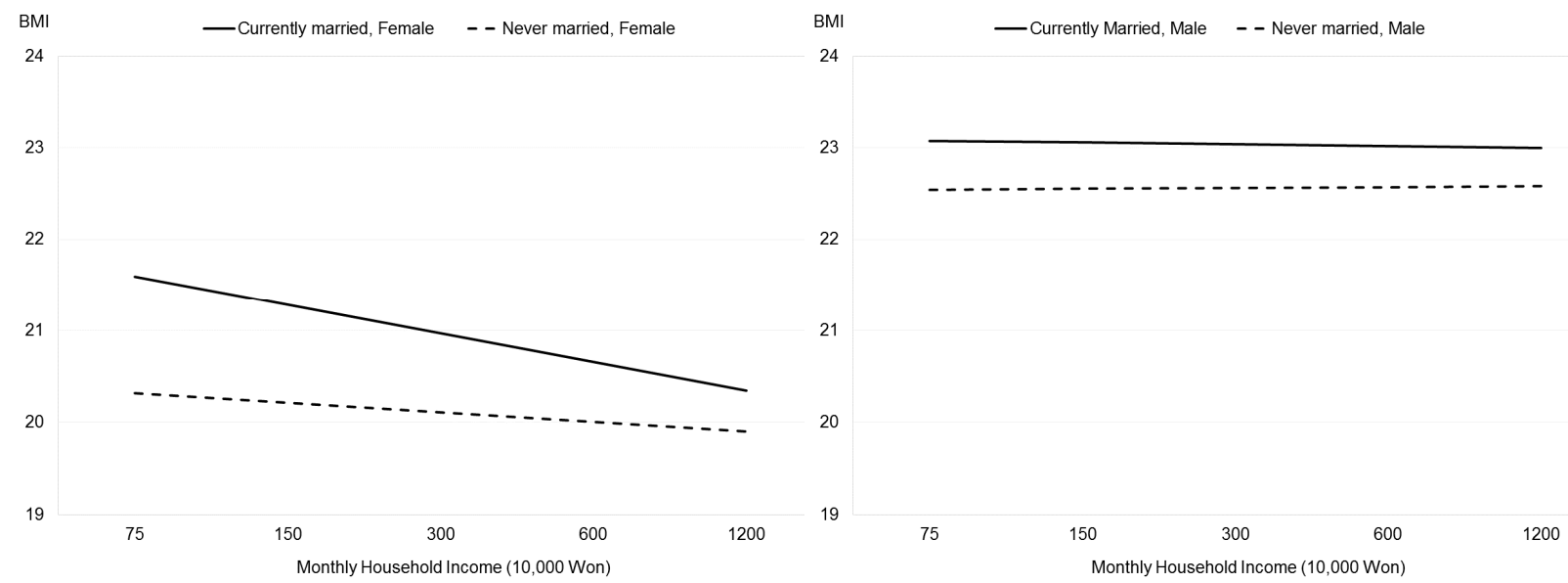

(Group F1: Female, South Korea, 2007-2014)

(Group M1: Male, South Korea, 2007-2014)

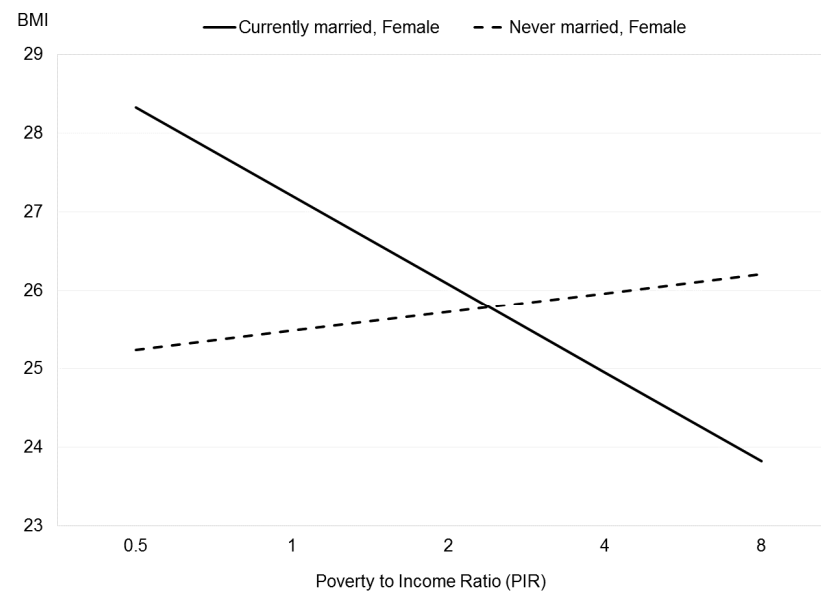

(Group F2: Female, USA, 1999-2014)

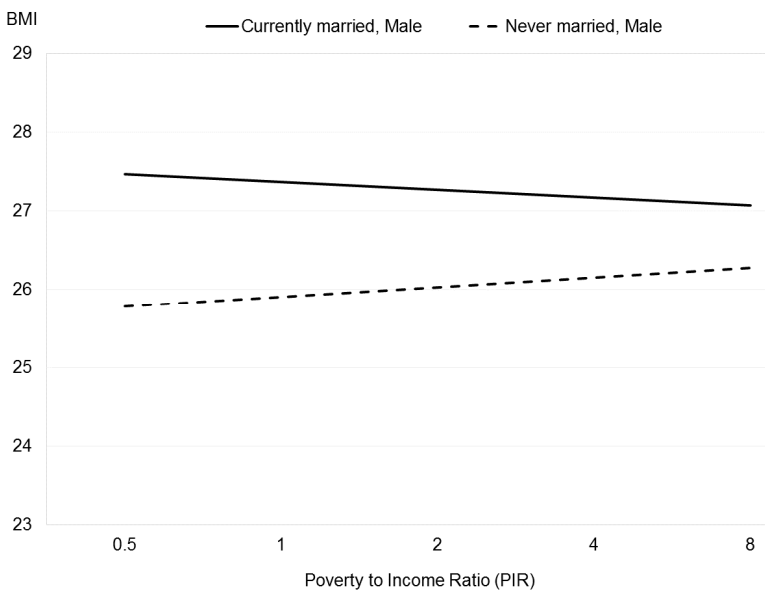

(Group M2: Male, USA, 1999-2014)

Note: estimated for a average respondent, who was in his or her 20s, graduated high school, employed, did not try to lose weight, lived in a household with 3 family members, and gave birth to one live child (only female) in 2010 or 2009-2010 survey year. 


\section{REFERENCES}

Adler, Nancy E. and Katherine Newman. 2002. "Socioeconomic Disparities in Health: Pathways and Policies." Health Affairs (Project Hope) 21(2):60-76.

Averett, Susan L. and Sanders Korenman. 1993. "The Economic Reality of the Beauty Myth." National Bureau of Economic Research: w4521.

Averett, Susan L., Asia Sikora and Laura M. Argys. 2008. "For Better Or Worse: Relationship Status and Body Mass Index." Economics \& Human Biology 6(3):330-349.

Baum, Charles L. and William F. Ford. 2004. "The Wage Effects of Obesity: A Longitudinal Study." Health Economics 13(9):885-899.

Blatt, Alexandria D., Liane S. Roe and Barbara J. Rolls. 2011. "Increasing Protein Content of Meals and its Effect on Daily Energy Intake." Journal of the American Dietetic Association 11(2):290-294.

Bozoyan, Christiane and Tobias Wolbring. 2011. "Fat, Muscles, and Wages." Economics \& Human Biology 9(4):356-363.

Brooks, Rob C., Stephen J. Simpson and David Raubenheimer. 2010. "The Price of Protein: Combining Evolutionary and Economic Analysis to Understanding Excessive Energy Consumption." Obesity Reviews 11(12):887-894.

Brown, Peter J. and Melvin Konner. 1987. "An Anthropological Perspective on Obesity." Annals of the New York Academy of Sciences 499(1):29-46. 
Bujnowski, Deborah, Pengcheng Xun, Martha L. Daviglus, Linda Van Horn, Ka He and Jeremiah Stamler. 2011. "Longitudinal Association between Animal and Vegetable Protein Intake and Obesity among Men in the United States: The Chicago Western Electric Study." Journal of American Dietetic Association 111(8):1150-1155.

Burdett, Ken and Melvyn G. Coles. 2001. "Transplants and Implants: The Economics of SelfImprovement." International Economic Review 42(3):597-616.

Caliendo, Marco and Wang-Sheng Lee. 2013. "Fat Chance! Obesity and the Transition from Unemployment to Employment." Economics \& Human Biology 11(2):121-133.

Carmalt, Julie H., John Cawley, Kara Joyner and Jeffery Sobal. 2008. "Body Weight and Matching with a Physically Attractive Romantic Partner." Journal of Marriage and Family 70(5):1287-1296.

Cawley, John. 2004. "The Impact of Obesity on Wages." Journal of Human Resources $34(2): 451-474$.

Centers for Disease Control and Prevention (CDC). 1999-2014. Continuous National Health and Nutrition Examination Survey Data. Hyattsville, MD: U.S. Department of Health and Human Services, Centers for Disease Control and Prevention, (http://wwwn.cdc.gov/nchs/nhanes/search/nhanes_continuous.aspx).

Centers for Disease Control and Prevention (CDC). 2014. "About the National Health and Nutrition Examination Survey.” Retrieved September 5, 2016 (http://www.cdc.gov/nchs/nhanes/about_nhanes.htm). 
Chen, Eunice Y. and Molly Brown. 2005. "Obesity Stigma in Sexual Relationships." Obesity Research 13(8):1393-1397.

Chiappori, Pierre-André, Sonia Oreffice and Climent Quintana-Domeque. 2012. "Fatter Attraction: Anthropometric and Socioeconomic Matching on the Marriage Market." Journal of Political Economy 120(4):659-695.

Conley, Dalton and Rebecca Glauber. 2007. "Gender, Body Mass, and Socioeconomic Status: New Evidence from the PSID." Advances in Health Economics and Health Services Research 17:253-275.

Crandall, Christian S. and Kristin L. Schiffhauer. 1998. "Anti-fat Prejudice: Beliefs, Values, and American Culture." Obesity Research 6(6):458-460.

Crosnoe, Robert, and Chandra Muller. 2004. "Body Mass Index, Academic Achievement, and School Context: Examining the Educational Experiences of Adolescents at Risk of Obesity." Journal of Health and Social Behavior 45(4): 393-407.

Dinsa, Goryakin D., Yevgenly Goryakin, Elena Fumagalli and Mark Suhrcke. 2012. "Obesity and Socioeconomic Status in Developing Countries: A Systematic Review." Obesity Reviews 13(11):1067-1079.

Drewnowski, Adam. 2009. "Obesity, Diets, and Social Inequalities." Nutrition Reviews 67(Suppl 1):S36-S39.

Drewnowski, Adam. and Nicole Darmon. 2005. "The Economics of Obesity: Dietary Energy Density and Energy Cost." The American Journal of Clinical Nutrition 82(1):265S-273S. 
Drewnowski, Adam and S. E. Specter. 2004. "Poverty and Obesity: The Role of Energy Density and Energy Costs." The American Journal of Clinical Nutrition 79(1):6-16.

Duffey, Kiyah J. and Barry M. Popkin. 2011. "Energy Density, Portion Size, and Eating Occasions: Contributions to Increased Energy Intake in the United States, 1977-2006." PLoS Med 8(6):1-8.

Eaton, S. Boyd, Melvin Konner and Marjorie Shostak. 1988. "Stone Agers in the Fast Lane: Chronic Degenerative Diseases in Evolutionary Perspective." The American Journal of Medicine 84(4):739-749.

Flint, Stuart W. and Jeremé Snook. 2014. "Obesity and Discrimination the Next 'big Issue'?" International Journal of Discrimination and the Law:1358229114534550.

Giskes, Katrina, Frank J. Lenthe, Gavin Turrell, Carlijn Kamphuis, Johannes Brug, and Johan P. Mackenbach. 2008. "Socioeconomic Position at Different Stages of the Life Course and Its Influence on Body Weight and Weight Gain in Adulthood: A Longitudinal Study with 13-Year Follow-up." Obesity 16 (6): 1377-1381.

Glass, Christy M., Steven A. Haas, and Eric N. Reither. 2010. "The Skinny on Success: Body Mass, Gender and Occupational Standing across the Life Course." Social Forces 88(4): 17771806.

Gordon-Larsen, Penny, Melissa C. Nelson, Phil Page and Barry M. Popkin. 2006. "Inequality in the Built Environment Underlies Key Health Disparities in Physical Activity and Obesity." Pediatrics 117(2):417-424. 
Greenberg, Bradley S., Matthew Eastin, Lachlan Hofschire, Ken Lachlan and Kelly D. Brownell. 2003. "Portrayals of Overweight and Obese Individuals on Commercial Television." American Journal of Public Health 93(8):1342-1348.

Han, Euna, Edward C. Norton and Lisa M. Powell. 2011. "Direct and Indirect Effects of Body Weight on Adult Wages." Economics \& Human Biology 9(4):381-392.

Han, Euna, Edward C. Norton and Sally C. Stearns. 2009. "Weight and Wages: Fat Versus Lean Paychecks." Health Economics 18(5):535-548.

House, James S. 2002. "Understanding Social Factors and Inequalities in Health: 20th Century Progress and 21st Century Prospects." Journal of Health and Social Behavior:125-142.

Hruschka, Daniel J. 2017. "From Thin to Fat and Back Again: A Dual Process Model of the Big Body Mass Reversal." Pp. 15-32 in Fat Planet: Obesity, Culture, and Symbolic Body Capital, edited by Anderson-Fye, Eileen and A. Brewis. SAR Press and University of New Mexico Press.

Hruschka, Ddaniel J. and Craig Hadley. 2016. "How Much do Universal Anthropometric Standards Bias the Global Monitoring of Obesity and Undernutrition?" Obesity Reviews, DOI: 10.1111/obr.12449.

Hruschka, Daniel J. 2012. "Do Economic Constraints on Food Choice make People Fat? A Critical Review of Two Hypotheses for the Poverty-obesity Paradox." American Journal of Human Biology 24(3):277-285. 
Hruschka, Daniel J., Craig Hadley and Alexandra Brewis. 2014. "Disentangling Basal and Accumulated Body Mass for Cross-population Comparisons." American Journal of Physical Anthropology 153(4):542-550.

Hruschka, Daniel J, Elaine C. Rush and Alexandra A. Brewis. 2013. "Population Differences in the Relationship between Height, Weight, and Adiposity: An Application of Burton's Model." American Journal of Physical Anthropology 151(1): 68-76.

Judge, Timothy A. and Daniel M. Cable. 2011. "When it Comes to Pay, do the Thin Win? the Effect of Weight on Pay for Men and Women." Journal of Applied Psychology 96(1):95.

Jung, Jaehee and Seung-Hee Lee. 2006. "Cross-cultural Comparisons of Appearance Selfschema, Body Image, Self-esteem, and Dieting Behavior between Korean and US Women." Family and Consumer Sciences Research Journal 34(4):350-365.

Kassirer, Jerome P. and Marcia Angell. 1998. "Losing Weight--an Ill-Fated New Year's Resolution." New England Journal of Medicine 338(1):52-54.

Klos, Lori A. and Jeffery Sobal. 2013. "Marital Status and Body Weight, Weight Perception, and Weight Management among US Adults." Eating Behaviors 14(4):500-507.

Korea Centers for Disease Control and Prevention (KCDC). 2014. “About the Korea National Health and Nutrition Examination Survey: Survey Overview.” Retrieved September 5, 2016 (https://knhanes.cdc.go.kr/knhanes/eng/index.do).

Korea Centers for Disease Control and Prevention (KCDC). 2007. The fourth Korea National Health and Nutrition Examination Survey (KNHANES IV-1, 2, and 3). 
Korea Centers for Disease Control and Prevention (KCDC). 2010. The Fifth Korea National Health and Nutrition Examination Survey (KNHANES V-1, 2, and 3).

Korea Centers for Disease Control and Prevention (KCDC). 2013. The Sixth Korea National Health and Nutrition Examination Survey (KNHANES VI-1 and 2).

Lin, Y., s. Bolca, S. Vandevijvere, S. De Vreise, T. Mouratidou, M. De Neve, A. Polet, H. Van Oyen, J. Van Camp, G. De Backer, S. De Henauw and I. Huybrechts. 2011. "Plant and Animal Protein Intake and its Association with Overweith and Obesity among the Belgian Population." British Journal of Nutrition 105:1106-1116.

Malcolm, Michael and Ilker Kaya. 2016. "Selection Works both Ways: BMI and Marital Formation among Young Women." Review of Economics of the Household 14(2):293-311.

Marini, Maddalena, Natarajan Sriram, Konrad Schnabel, Norbert Maliszewski, Thierry Devos, Bo Ekehammar, Reinout Wiers, Cai HuaJian, Mónika Somogyi and Kimihiro Shiomura. 2013. "Overweight People have Low Levels of Implicit Weight Bias, but Overweight Nations have High Levels of Implicit Weight Bias." PloS One 8(12):e83543.

Mason, Katherine. 2012. "The Unequal Weight of Discrimination: Gender, Body Size, and Income Inequality." Social Problems 59(3):411-435.

McClintock, Elizabeth A. 2014. "Beauty and Status the Illusion of Exchange in Partner Selection?" American Sociological Review: 0003122414536391.

Monteiro, Carlos A., Wolney L. Conde, Bing Lu and Barry M. Popkin. 2004. "Obesity and Inequities in Health in the Developing World." International Journal of Obesity 28:1181-1186. 
Monteiro, Carlos A., Conde, Wolney L., and Popkin, Barry M. 2001. "Independent Effects of Income and Education on the Risk of Obesity in the Brazilian Adult Population." The Journal of Nutrition 131(3): 881S-886S.

Morris, Stephen. 2007. "The Impact of Obesity on Employment." Labour Economics 14(3):413433.

Mosca, Irene. 2013. "Body Mass Index, Waist Circumference and Employment: Evidence from Older Irish Adults." Economics \& Human Biology 11(4): 522-533.

Mukhopadhyay, Sankar. 2008. "Do Women Value Marriage More? the Effect of Obesity on Cohabitation and Marriage in the USA." Review of Economics of the Household 6(2):111-126.

Olafsdottir, Sigrun. 2007. "Fundamental Causes of Health Disparities: Stratification, the Welfare State, and Health in the United States and Iceland." Journal of Health and Social Behavior 48(3):239-253.

Oreffice, Sonia and Climent Quintana-Domeque. 2016. "Beauty, Body Size and Wages: Evidence from a Unique Data Set." Economics \& Human Biology 22:24-34.

Oreffice, Sonia and Climent Quintana-Domeque. 2010. "Anthropometry and Socioeconomics among Couples: Evidence in the United States." Economics \& Human Biology 8(3):373-384.

Pampel, Fred C., Patrick M. Krueger and Justin T. Denney. 2010. "Socioeconomic Disparities in Health Behaviors." Annual Review of Sociology 36:349-370. 
Pan, Jay, Xuezheng Qin and Gordon G. LIU. 2012. "The Impact of Body Size on Urban Employment: Evidence from China." China Economic Review 27: 249-263.

Parsons, Tessa J., Chris Power, Stuart Logan, and C. D. Summerbelt. 1999. "Childhood Predictors of Adult Obesity: a Systematic Review." International Journal of Obesity 23 (Suppl 8): S1-S107.

Phelan, Jo C., Bruce G. Link and Parisa Tehranifar. 2010. "Social Conditions as Fundamental Causes of Health Inequalities: Theory, Evidence, and Policy Implications." Journal of Health and Social Behavior 51(Suppl):S28-40.

Ponzo, Michela and Vincenzo Scoppa. 2015. "Trading Height for Education in the Marriage Market." American Journal of Human Biology 27(2):164-174.

Pudrovska, Tetyana, Eric N. Reither, Ellis S. Logan, and Kyler J. Sherman-Wilkins. 2014. "Gender and Reinforcing Associations between Socioeconomic Disadvantage and Body Mass over the Life Course." Journal of Health and Social Behavior 55(3): 283-301.

Puhl, Rebecca M., Tatiana Andreyeva and Kelly D. Brownell. 2008. "Perceptions of Weight Discrimination: Prevalence and Comparison to Race and Gender Discrimination in America." International Journal of Obesity 32(6):992-1000.

Puhl, Rebecca M. and Kelly D. Brownell. 2003. "Psychosocial Origins of Obesity Stigma: Toward Changing a Powerful and Pervasive Bias." Obesity Reviews 4(4):213-227.

Puhl, Rebecca M. and Chelsea A. Heuer. 2009. "The Stigma of Obesity: A Review and Update." Obesity 17(5):941-964. 
Sassler, Sharon and Kara Joyner. 2011. "Social Exchange and the Progression of Sexual Relationships in Emerging Adulthood." Social Forces 90(1):223-245.

Schwekendiek, Daniel, Y. Minhee and Stanley Ulijaszek. 2013. "On Slimming Pills, Growth Hormones, and Plastic Surgery: The Socioeconomic Value of the Body in South Korea." When Culture Impacts Health: Global Lessons for Effective Health Research:141-153.

Simpson, Stephen. J. and David Raubenheicmer. 2005. "Obesity: The Protein Leverage Hypothesis." Obesity Reviews 6:133-142.

Sobal, Jeffery and Albert J. Stunkard. 1989. "Socioeconomic Status and Obesity: A Review of the Literature." Psychological Bulletin 105(2):260.

Stevens, Gillian, Dawn Owens and Eric C. Schaefer. 1990. "Education and Attractiveness in Marriage Choices." Social Psychology Quarterly:62-70.

Subramanian, Subu V., Jessica M. Perkins, Emre Ozaltin and George D. Smith. 2011. "Weight of Nations: A Socioeconomic Analysis of Women in Low- to Middle-Income Countries." The American Journal of Clinical Nutrition 93(2):413-421.

Taylor, Patricia A. and Norval D. Glenn. 1976. "The Utility of Education and Attractiveness for Females' Status Attainment through Marriage." American Sociological Review:484-498.

Udry, J R. 1977. "The Importance of being Beautiful: A Reexamination and Racial Comparison." American Journal of Sociology:154-160. 
Umberson, Debra, Hui Liu, and Daniel Powers. 2009. "Marital Status, Marital Transitions, and Body Weight." Journal of Health and Social Behavior 50(3): 327-343.

Vinknes, Kathrine J., Stefan de Vogel, Amany K. Elshorbagy, Eha Nurk, Christian A. Drevon, Clara G. Gjesdal, Grethe S. Tell, Stein E. Vollset and Helga Refsum. 2011. "Dietary Intake of Protein is Positively Associated with Percent Body Fat in Middle-Aged and Older Adults." The Journal of Nutrition 141(3):440-446.

Wada, Roy and Erdal Tekin. 2010. "Body Composition and Wages." Economics \& Human Biology 8(2):242-254. 
$<$ Appendix 1a $>$ Regression Estimates of Body Mass Index (BMI) on Household Income, Marital and Employment Status, Female, Not Weighted, Korea (2007-2014) and USA (19992014)

\begin{tabular}{|c|c|c|c|c|c|c|c|c|}
\hline \multirow{4}{*}{$\begin{array}{l} \\
\ln (\mathrm{HH} \text { income }) \\
* \text { Currently married }\end{array}$} & \multicolumn{4}{|c|}{ Korea, 2007-2014 } & \multicolumn{4}{|c|}{ USA, 1999-2014 } \\
\hline & \multirow{2}{*}{\multicolumn{2}{|c|}{$\begin{array}{l}\text { Model } 1 \\
\text { B (S.E.) }\end{array}$}} & \multirow{2}{*}{\multicolumn{2}{|c|}{$\begin{array}{l}\text { Model } 2 \\
\text { B (S.E.) }\end{array}$}} & \multirow{2}{*}{\multicolumn{2}{|c|}{$\begin{array}{l}\text { Model } 1 \\
\text { B (S.E.) }\end{array}$}} & \multirow{2}{*}{\multicolumn{2}{|c|}{$\begin{array}{l}\text { Model } 2 \\
\text { B (S.E.) }\end{array}$}} \\
\hline & & & & & & & & \\
\hline & & & $\begin{array}{l}-0.25 \\
(0.09)\end{array}$ & ** & & & $\begin{array}{l}-1.47 \\
(0.39)\end{array}$ & *** \\
\hline $\begin{array}{l}\ln (\mathrm{HH} \text { income }) \\
* \text { Employed }\end{array}$ & & & $\begin{array}{c}0.11 \\
(0.08)\end{array}$ & & & & $\begin{array}{c}0.46 \\
(0.39)\end{array}$ & \\
\hline $\ln (\mathrm{HH}$ income $)$ & $\begin{array}{l}-0.43 \\
(0.04)\end{array}$ & ${ }^{* * *}$ & $\begin{array}{c}-0.32 \\
(0.09)\end{array}$ & *** & $\begin{array}{l}-1.07 \\
(0.22)\end{array}$ & $* * *$ & $\begin{array}{l}-0.51 \\
(0.36)\end{array}$ & \\
\hline Currently married & $\begin{array}{c}0.86 \\
(0.11)\end{array}$ & $* * *$ & $\begin{array}{c}2.26 \\
(0.52)\end{array}$ & *** & $\begin{array}{l}-0.06 \\
(0.40)\end{array}$ & & $\begin{array}{c}1.12 \\
(0.51)\end{array}$ & * \\
\hline Employed & $\begin{array}{c}0.08 \\
(0.06)\end{array}$ & & $\begin{array}{l}-0.58 \\
(0.48)\end{array}$ & & $\begin{array}{c}0.03 \\
(0.33)\end{array}$ & & $\begin{array}{l}-0.34 \\
(0.45)\end{array}$ & \\
\hline Attempt to lose weight & $\begin{array}{c}2.44 \\
(0.06)\end{array}$ & *** & $\begin{array}{c}2.45 \\
(0.06)\end{array}$ & **** & $\begin{array}{c}2.97 \\
(0.29)\end{array}$ & $* * *$ & $\begin{array}{c}3.00 \\
(0.29)\end{array}$ & *** \\
\hline Household size & $\begin{array}{c}0.15 \\
(0.03)\end{array}$ & *** & $\begin{array}{c}0.14 \\
(0.03)\end{array}$ & **** & $\begin{array}{c}0.21 \\
(0.13)\end{array}$ & & $\begin{array}{c}0.20 \\
(0.13)\end{array}$ & \\
\hline Parity $^{\mathrm{a}}$ & $\begin{array}{c}0.07 \\
(0.03)\end{array}$ & ** & $\begin{array}{c}0.08 \\
(0.03)\end{array}$ & ** & $\begin{array}{l}-0.31 \\
(0.16)\end{array}$ & * & $\begin{array}{l}-0.33 \\
(0.16)\end{array}$ & * \\
\hline \multicolumn{9}{|l|}{ Education $^{b}$} \\
\hline Less than high school & $\begin{array}{c}0.79 \\
(0.12)\end{array}$ & *** & $\begin{array}{c}0.75 \\
(0.12)\end{array}$ & $* * *$ & $\begin{array}{c}0.42 \\
(0.49)\end{array}$ & & $\begin{array}{c}0.22 \\
(0.49)\end{array}$ & \\
\hline College or above & $\begin{array}{l}-0.64 \\
(0.06)\end{array}$ & *** & $\begin{array}{l}-0.63 \\
(0.06)\end{array}$ & $* * *$ & $\begin{array}{l}-2.39 \\
(0.32)\end{array}$ & $* * *$ & $\begin{array}{l}-2.34 \\
(0.32)\end{array}$ & *** \\
\hline \multicolumn{9}{|l|}{ Age group $^{c}$} \\
\hline 30-39 years old & $\begin{array}{c}0.29 \\
(0.10)\end{array}$ & ** & $\begin{array}{c}0.31 \\
(0.10)\end{array}$ & $* *$ & $\begin{array}{c}2.19 \\
(0.40)\end{array}$ & $* * *$ & $\begin{array}{c}2.27 \\
(0.39)\end{array}$ & *** \\
\hline 40-49 years old & $\begin{array}{c}1.00 \\
(0.11)\end{array}$ & *** & $\begin{array}{c}1.04 \\
(0.12)\end{array}$ & $* * *$ & $\begin{array}{c}3.19 \\
(0.42)\end{array}$ & $* * *$ & $\begin{array}{c}3.30 \\
(0.42)\end{array}$ & $* * *$ \\
\hline Intercept & $\begin{array}{l}21.79 \\
(0.28) \\
\end{array}$ & *** & $\begin{array}{l}21.20 \\
(0.51) \\
\end{array}$ & *** & $\begin{array}{l}25.84 \\
(0.71) \\
\end{array}$ & $* * *$ & $\begin{array}{l}25.49 \\
(0.73) \\
\end{array}$ & *** \\
\hline R squared & .20 & & .20 & & .10 & & .11 & \\
\hline F statistic & 164.91 & & 148.15 & & $17.20^{* *}$ & & $16.28^{* *}$ & \\
\hline $\mathrm{N}$ & 11,25 & & 11,25 & & 2,605 & & 2,605 & \\
\hline
\end{tabular}

Note: ${ }^{*} p<.05 ;{ }^{* *} p<.01 ;{ }^{* * *} p<.001$, two tailed; year effects are controlled but omitted; ${ }^{\text {a }}$ gravity in Korea; Reference categories: ${ }^{b}$ high school graduate as a reference group; ${ }^{c} 20-29$ years old as a reference group. 
$<$ Appendix 1b $>$ Regression Estimates of Body Mass Index (BMI) on Household Income, Marital and Employment Status, Male, Not Weighted, Korea (2007-2014) and USA (19992014)

\begin{tabular}{|c|c|c|c|c|c|c|c|c|}
\hline & \multicolumn{4}{|c|}{ Korea, 2007-2014 } & \multicolumn{4}{|c|}{ USA, 1999-2014 } \\
\hline & \multirow{2}{*}{\multicolumn{2}{|c|}{$\begin{array}{l}\text { Model } 1 \\
\text { B (S.E.) }\end{array}$}} & \multirow{2}{*}{\multicolumn{2}{|c|}{$\begin{array}{l}\text { Model } 2 \\
\text { B (S.E.) }\end{array}$}} & \multirow{2}{*}{\multicolumn{2}{|c|}{$\begin{array}{l}\text { Model } 1 \\
\text { B (S.E.) }\end{array}$}} & \multirow{2}{*}{\multicolumn{2}{|c|}{$\frac{\text { Model } 2}{\text { B (S.E.) }}$}} \\
\hline & & & & & & & & \\
\hline $\begin{array}{l}\ln (\mathrm{HH} \text { income }) \\
* \text { Currently married }\end{array}$ & \multicolumn{6}{|c|}{$\begin{array}{l}-0.04 \\
(0.10)\end{array}$} & \multicolumn{2}{|l|}{$\begin{array}{l}-0.01 \\
(0.30)\end{array}$} \\
\hline $\begin{array}{l}\ln (\mathrm{HH} \text { income }) \\
* \text { Employed }\end{array}$ & \multicolumn{4}{|c|}{$\begin{array}{c}0.12 \\
(0.11)\end{array}$} & & & \multicolumn{2}{|l|}{$\begin{array}{l}-0.18 \\
(0.36)\end{array}$} \\
\hline $\ln (\mathrm{HH}$ income $)$ & \multicolumn{2}{|l|}{$\begin{array}{l}-0.05 \\
(0.05)\end{array}$} & \multicolumn{2}{|l|}{$\begin{array}{l}-0.12 \\
(0.09)\end{array}$} & $\begin{array}{c}0.08 \\
(0.16)\end{array}$ & & \multicolumn{2}{|l|}{$\begin{array}{c}0.22 \\
(0.31)\end{array}$} \\
\hline Currently married & $\begin{array}{c}0.36 \\
(0.10)\end{array}$ & $* * *$ & $\begin{array}{c}0.60 \\
(0.56)\end{array}$ & & $\begin{array}{c}0.78 \\
(0.28)\end{array}$ & ** & $\begin{array}{c}0.79 \\
(0.39)\end{array}$ & * \\
\hline Employed & $\begin{array}{c}0.03 \\
(0.11)\end{array}$ & & $\begin{array}{l}-0.65 \\
(0.63)\end{array}$ & & $\begin{array}{l}-0.92 \\
(0.31)\end{array}$ & ** & $\begin{array}{l}-0.83 \\
(0.36)\end{array}$ & * \\
\hline Attempt to lose weight & $\begin{array}{l}2.98 \\
(0.07)\end{array}$ & $* * *$ & $\begin{array}{c}2.98 \\
(0.07)\end{array}$ & $* * *$ & $\begin{array}{c}3.96 \\
(0.25)\end{array}$ & $* * *$ & $\begin{array}{c}3.97 \\
(0.25)\end{array}$ & $* * *$ \\
\hline Household size & $\begin{array}{c}0.01 \\
(0.03)\end{array}$ & & $\begin{array}{c}0.01 \\
(0.03)\end{array}$ & & $\begin{array}{c}0.01 \\
(0.08)\end{array}$ & & $\begin{array}{c}0.00 \\
(0.08)\end{array}$ & \\
\hline \multicolumn{9}{|l|}{ Education $^{a}$} \\
\hline Less than high school & $\begin{array}{c}0.11 \\
(0.15)\end{array}$ & & $\begin{array}{c}0.11 \\
(0.15)\end{array}$ & & $\begin{array}{l}-0.29 \\
(0.36)\end{array}$ & & $\begin{array}{l}-0.29 \\
(0.36)\end{array}$ & \\
\hline College or above & $\begin{array}{c}0.09 \\
(0.07)\end{array}$ & & $\begin{array}{c}0.08 \\
(0.07)\end{array}$ & & $\begin{array}{l}-1.38 \\
(0.25)\end{array}$ & $* * *$ & $\begin{array}{l}-1.37 \\
(0.26)\end{array}$ & $* * *$ \\
\hline \multicolumn{9}{|l|}{ Age group ${ }^{b}$} \\
\hline 30-39 years old & $\begin{array}{c}0.42 \\
(0.11)\end{array}$ & $* * *$ & $\begin{array}{c}0.42 \\
(0.11)\end{array}$ & $* * *$ & $\begin{array}{c}1.70 \\
(0.29)\end{array}$ & *** & $\begin{array}{c}1.71 \\
(0.29)\end{array}$ & $* * *$ \\
\hline 40-49 years old & $\begin{array}{c}0.30 \\
(0.12)\end{array}$ & * & $\begin{array}{c}0.29 \\
(0.12)\end{array}$ & * & $\begin{array}{c}2.32 \\
(0.31)\end{array}$ & ${ }_{* * *}$ & $\begin{array}{l}2.33 \\
(0.31)\end{array}$ & $* * *$ \\
\hline Intercept & $\begin{array}{l}22.96 \\
(0.28) \\
\end{array}$ & ${ }_{* * *}^{*}$ & $\begin{array}{l}23.34 \\
(0.50) \\
\end{array}$ & $* * *$ & $\begin{array}{l}25.83 \\
(0.53) \\
\end{array}$ & ${ }_{* * *}$ & $\begin{array}{l}25.78 \\
(0.54) \\
\end{array}$ & $* * *$ \\
\hline R squared & \multicolumn{2}{|l|}{.20} & \multicolumn{2}{|l|}{.20} & \multicolumn{2}{|c|}{.12} & \multicolumn{2}{|l|}{.12} \\
\hline F statistic & \multicolumn{2}{|c|}{$135.60^{* * *}$} & \multicolumn{2}{|c|}{$120.59^{* * *}$} & \multicolumn{2}{|c|}{$26.58^{* * *}$} & \multicolumn{2}{|c|}{$23.63^{* * *}$} \\
\hline $\mathrm{N}$ & \multicolumn{2}{|c|}{8,895} & \multicolumn{2}{|c|}{8,895} & \multicolumn{2}{|c|}{3,132} & \multicolumn{2}{|c|}{3,132} \\
\hline
\end{tabular}

Note: ${ }^{*} p<.05 ;{ }^{* *} p<.01 ;{ }^{* * *} p<.001$, two tailed; year effects are controlled but omitted; Reference categories: ${ }^{a}$ high school graduate as a reference group; ${ }^{\mathrm{b}} 20-29$ years old as a reference group. 
$<$ Appendix 2a $>$ Regression Estimates of Body Mass Index (BMI) on Household Income by Age, Currently Married, Korea (2007-2014) and USA (1999-2014)

\begin{tabular}{|c|c|c|c|c|c|c|c|c|}
\hline & \multicolumn{4}{|c|}{ Korea, 2007-2014 } & \multicolumn{4}{|c|}{ USA, 1999-2014 } \\
\hline & \multirow{2}{*}{\multicolumn{2}{|c|}{$\begin{array}{c}\text { Female } \\
\text { B (S.E.) }\end{array}$}} & \multicolumn{2}{|l|}{ Male } & \multirow{2}{*}{\multicolumn{2}{|c|}{$\begin{array}{c}\text { Female } \\
\text { B (S.E.) }\end{array}$}} & \multirow{2}{*}{\multicolumn{2}{|c|}{$\begin{array}{r}\text { Male } \\
\text { B (S.E.) }\end{array}$}} \\
\hline & & & B (S.E.) & & & & & \\
\hline $\begin{array}{l}\ln (\text { HH income }) \\
* 30-39 \text { years old }\end{array}$ & $\begin{array}{l}-0.33 \\
(0.29)\end{array}$ & & $\begin{array}{c}1.19 \\
(0.50)\end{array}$ & * & $\begin{array}{l}-0.62 \\
(0.76)\end{array}$ & & $\begin{array}{l}-1.47 \\
(0.72)\end{array}$ & * \\
\hline $\begin{array}{l}\ln (\mathrm{HH} \text { income }) \\
* 40-49 \text { years old }\end{array}$ & $\begin{array}{l}-0.01 \\
(0.27)\end{array}$ & & $\begin{array}{c}1.17 \\
(0.49)\end{array}$ & * & $\begin{array}{l}-0.23 \\
(0.63)\end{array}$ & & $\begin{array}{l}-0.56 \\
(0.65)\end{array}$ & \\
\hline $\ln (\mathrm{HH}$ income $)$ & $\begin{array}{l}-0.33 \\
(0.26)\end{array}$ & & $\begin{array}{l}-1.17 \\
(0.49)\end{array}$ & * & $\begin{array}{l}-1.50 \\
(0.53)\end{array}$ & ** & $\begin{array}{c}0.91 \\
(0.48)\end{array}$ & \\
\hline Employed & $\begin{array}{l}-0.02 \\
(0.08)\end{array}$ & & $\begin{array}{c}0.77 \\
(0.22)\end{array}$ & $* * *$ & $\begin{array}{c}0.78 \\
(0.33)\end{array}$ & * & $\begin{array}{c}-1.12 \\
(0.51)\end{array}$ & * \\
\hline Attempt to lose weight & $\begin{array}{l}2.45 \\
(0.08)\end{array}$ & $* * *$ & $\begin{array}{l}2.78 \\
(0.09)\end{array}$ & $* * *$ & $\begin{array}{c}3.08 \\
(0.33)\end{array}$ & $* * *$ & $\begin{array}{c}3.43 \\
(0.32)\end{array}$ & $* * *$ \\
\hline Household size & $\begin{array}{c}0.15 \\
(0.04)\end{array}$ & $* * *$ & $\begin{array}{c}0.03 \\
(0.05)\end{array}$ & & $\begin{array}{c}0.25 \\
(0.20)\end{array}$ & & $\begin{array}{c}0.15 \\
(0.11)\end{array}$ & \\
\hline Parity ${ }^{b}$ & $\begin{array}{c}0.07 \\
(0.03)\end{array}$ & * & & & $\begin{array}{l}-0.34 \\
(0.20)\end{array}$ & & & \\
\hline \multicolumn{9}{|l|}{ Education $^{c}$} \\
\hline Less than high school & $\begin{array}{c}0.66 \\
(0.15)\end{array}$ & $* * *$ & $\begin{array}{c}0.23 \\
(0.18)\end{array}$ & & $\begin{array}{l}-0.40 \\
(0.54)\end{array}$ & & $\begin{array}{l}-0.89 \\
(0.64)\end{array}$ & \\
\hline College or above & $\begin{array}{l}-0.79 \\
(0.09)\end{array}$ & $* * *$ & $\begin{array}{c}0.07 \\
(0.09)\end{array}$ & & $\begin{array}{l}-2.55 \\
(0.34)\end{array}$ & $* * *$ & $\begin{array}{l}-1.70 \\
(0.26)\end{array}$ & $* * *$ \\
\hline \multicolumn{9}{|l|}{ Age group ${ }^{d}$} \\
\hline 30-39 years old & $\begin{array}{l}1.95 \\
(1.70)\end{array}$ & & $\begin{array}{l}-6.63 \\
(3.01)\end{array}$ & * & $\begin{array}{l}2.06 \\
(0.99)\end{array}$ & * & $\begin{array}{c}2.64 \\
(0.89)\end{array}$ & $* *$ \\
\hline $40-49$ years old & $\begin{array}{c}0.78 \\
(1.58)\end{array}$ & & $\begin{array}{l}-6.69 \\
(2.95)\end{array}$ & $*$ & $\begin{array}{c}2.52 \\
(0.78)\end{array}$ & $* *$ & $\begin{array}{c}2.03 \\
(0.78)\end{array}$ & $*$ \\
\hline Intercept & $\begin{array}{l}22.29 \\
(1.52) \\
\end{array}$ & $* * *$ & $\begin{array}{l}29.27 \\
(2.86) \\
\end{array}$ & $* * *$ & $\begin{array}{l}25.98 \\
(0.96) \\
\end{array}$ & $* * *$ & $\begin{array}{l}26.23 \\
(0.88) \\
\end{array}$ & $* * *$ \\
\hline R squared & .19 & & .18 & & .11 & & .12 & \\
\hline F statistic & $68.50^{*}$ & & 83.03 & & 17.31 & & 20.76 & \\
\hline $\mathrm{N}^{\mathrm{e}}$ & 6,128 & & 9,07 & & 2,13 & & 2,23 & \\
\hline
\end{tabular}

Note: ${ }^{*} p<.05 ;{ }^{* *} p<.01 ;{ }^{* * *} p<.001$, two tailed; adjusted for sample weight; year effects are controlled but omitted; ${ }^{\mathrm{b}}$ gravity in Korea; Reference categories: ${ }^{a}$ interaction between income and 20-29 years old as a reference group; ${ }^{c}$ high school graduate as a reference group; ${ }^{\mathrm{d}} 20-29$ years old as a reference group; ${ }^{\mathrm{e}}$ the full number of cases (pre-weight) including those with missing values in one or more variables since PROC SURVEYMEANS statement is used with NOMCAR and DOMAIN options. 
$<$ Appendix 2b $>$ Regression Estimates of Body Mass Index (BMI) on Household Income by Age, Never Married, Korea (2007-2014) and USA (1999-2014)

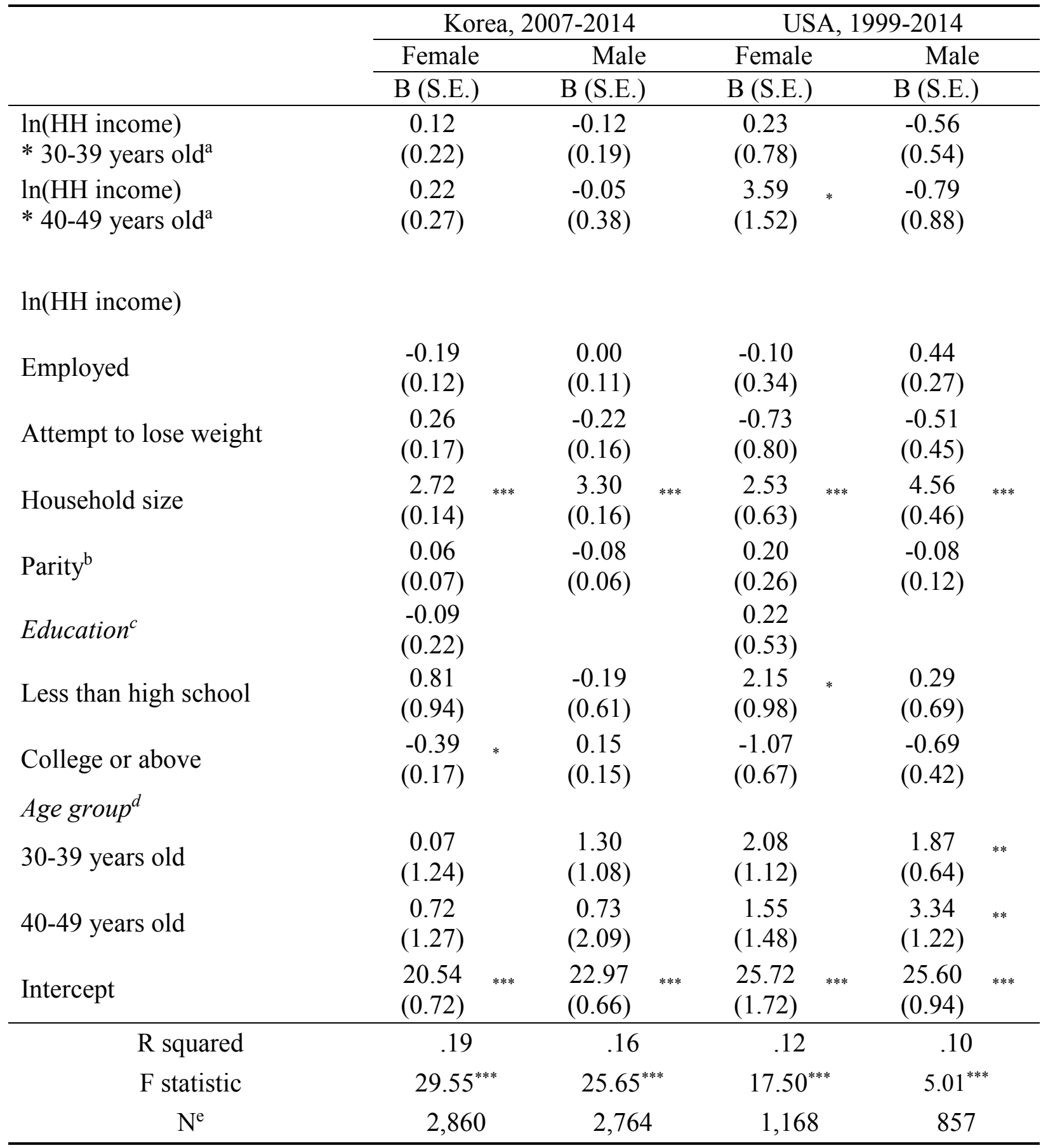

Note: ${ }^{*} p<.05 ;{ }^{* *} p<.01 ;{ }^{* * *} p<.001$, two tailed; adjusted for sample weight; year effects are controlled but omitted; ${ }^{\mathrm{b}}$ gravity in Korea; Reference categories: ${ }^{a}$ interaction between income and $20-29$ years old as a reference group; ${ }^{c}$ high school graduate as a reference group; ${ }^{\mathrm{d}} 20-29$ years old as a reference group; ${ }^{\mathrm{e}}$ the full number of cases (pre-weight) including those with missing values in one or more variables since PROC SURVEYMEANS statement is used with NOMCAR and DOMAIN options. 
$<$ Appendix 3> Estimated Effects of Income on Body Mass Index by Marital Status including Cohabiting with Currently Married, USA (1999-2014)

\begin{tabular}{ccccc}
\hline & \multicolumn{2}{c}{ Female } & & Male \\
\cline { 2 - 5 } & $\begin{array}{c}\text { Currently Married } \\
\text { or Cohabiting }\end{array}$ & $\begin{array}{c}\text { Never } \\
\text { married }\end{array}$ & $\begin{array}{c}\text { Currently Married } \\
\text { or Cohabiting }\end{array}$ & $\begin{array}{c}\text { Never } \\
\text { married }\end{array}$ \\
\hline USA, 1999-2014 & -1.439 & 0.009 & 0.601 & 0.627 \\
$(-2.217 ;-0.660)$ & $(-0.838 ; 0.856)$ & $(-0.070 ; 1.271)$ & $(-0.208 ; 1.461)$ \\
\hline
\end{tabular}

Note: $95 \%$ Bonferroni adjusted confidence interval in parentheses; adjusted for sample weight. 
<Appendix 4> Estimated Effects of Income on Body Mass Index by Employment Status, Korea (2007-2014) and USA (1999-2014)

\begin{tabular}{ccccc}
\hline & \multicolumn{2}{c}{ Female } & & Male \\
\cline { 2 - 5 } & Employed & Not Employed & Employed & Not Employed \\
\hline Korea, 2007-2014 & -0.151 & -0.219 & 0.014 & -0.166 \\
& $(-0.375 ; 0.072)$ & $(-0.472 ; 0.035)$ & $(-0.223 ; 0.251)$ & $(-0.465 ; 0.133)$ \\
USA, 1999-2014 & 0.350 & -0.204 & 0.181 & 0.573 \\
& $(-0.402 ; 1.101)$ & $(-1.097 ; 0.689)$ & $(-0.532 ; 0.894)$ & $(-0.333 ; 1.479)$ \\
\hline
\end{tabular}

Note: $95 \%$ Bonferroni adjusted confidence interval in parentheses; adjusted for sample weight. 
$<$ Appendix 5 $>$ Estimated Effects of Income on Body Mass Index by Age among NeverMarried Women, Korea (2007-2014) and USA (1999-2014)

\begin{tabular}{cc|cc}
\hline & $\begin{array}{c}\text { Age } \\
\text { group }\end{array}$ & Coefficient & 95\% Confidence Interval \\
\hline \multirow{3}{*}{ Korea, 2007-2014a } & $20 \mathrm{~s}$ & -0.195 & $(-0.472 ; 0.082)$ \\
& $30 \mathrm{~s}$ & -0.044 & $(-0.571 ; 0.482)$ \\
& $40 \mathrm{~s}$ & 0.093 & $(-0.595 ; 0.782)$ \\
\hline & $20 \mathrm{~s}$ & -0.273 & $(-1.189 ; 0.643)$ \\
USA, 1999-2014 & $30 \mathrm{~s}$ & -0.255 & $(-1.818 ; 1.307)$ \\
& $40 \mathrm{~s}$ & 3.142 & $(-0.829 ; 7.113)$ \\
\hline
\end{tabular}

Note: ${ }^{\text {a }}$ reference group is the $20 \mathrm{~s} ;{ }^{*} p<.05 ;{ }^{* *} p<.01 ;{ }^{* * *} p<.001$, two tailed test; $95 \%$ Bonferroni adjusted confidence intervals are reported; adjusted for sample weight. 